\title{
Morphofunctional and Ultrastructural Evaluation of Hip Joint Development in Human Fetuses
}

\author{
Evaluación Morfofuncional y Ultraestructural del Desarrollo \\ de la Articulación de la Cadera en Fetos Humanos
}

\author{
Mariane Cristina Donato Simões'; Rafael Gabaret Agopian²; Henrique Antônio \\ Berwanger de Amorim Cabrita ${ }^{3}$ \& Edson Aparecido Liberti ${ }^{1}$
}

SIMÕES, M. C. D.; AGOPIAN, R. G.; CABRITA, H. A. B. A. \& LIBERTI, E. A. Morphofunctional and ultrastructural evaluation of hip joint development in human fetuses. Int. J. Morphol., 37(4):1450-1455, 2019.

SUMMARY: The normal sequential development of the hip joint $(\mathrm{HJ})$ was considered for the evaluation of the morphological and ultrastructural aspects of the joint cartilage of the proximal femoral head epiphysis in human fetuses between 16 to 31 weeks of intra uterine life (IUL). Twenty human fetuses were fixed in $10 \%$ formalin solution. Fetuses were divided into 4 groups (n=5): Group 1 (G1): 16-19 weeks IUL; Group 2 (G2): 20-23 weeks IUL; Group 3 (G3): 24-27 weeks IUL and Group 4 (G4): 28-31 weeks IUL. The right moieties of the HJ were subjected to light microscopy to determine the chondrocyte area, volume, and density and the extracellular matrix (ECM) density. The collagen component in ECM was qualitatively evaluated using Safranin-O and picrosirius techniques under polarized light. The left portions were analyzed using scanning electron microscopy (SEM). The advance of age revealed a gradual increase in chondrocyte area and volume and in ECM density, and a decrease in chondrocyte density. The apparent prevalence of type II collagen fibers in G1 and type III collagen fibers in G4, as well as a balance between type I and III collagen fibers in G2 and G3 suggest a process of cartilaginous evolution and repair. The pantographic organization of the collagen fiber meshes from the depth to the cartilage surface of the femoral head suggests that the arcade collagen network architecture starts at the fetal stage, regardless of the compressive forces applied. The morphological data may contribute not only to a better understanding of the maturation and cartilage organization in this area but also to serve as a theoretical basis for aspects related to diseases and joint malformations.

KEY WORDS: Anatomy; Human fetus; Hip joint; Chondrocytes; Collagen.

\section{INTRODUCTION}

The great interest of researchers in the study of HJ may be based on its complexity and clinical importance (Walker \& Goldsmith, 1981). A morphological study of the normal development of the joint components is not only necessary for a better understanding of possible defects during structure development (Fukazawa et al., 2009) but it can also serve as a theoretical basis for therapeutic intervention and surgery strategies (Cluzel et al., 2013). Moreover, McCarthy (1993) and Tecklenburg et al. (2006) reported that proper treatments for birth defects require precise knowledge of normal development stages.

It is known that the normal development of the femoral head depends on the concentric relationship and the interactive dynamic stimulation between its shape and that of the acetabulum (Li et al., 2013). Thus, authors such as Jadin et al. (2005) focused on the importance of the morphometric parameters for characterizing density and organization of chondrocytes during growth and maturation of cartilage, considering that these parameters may contribute significantly to the understanding of the dynamics of tissue growth.

The present study evaluated the morphofunctional characteristics of the femur head cartilage in human fetuses between 16 and 31 weeks of IUL. The morphological data aimed at contributing to a better understanding of the HP evolution and providing support for treatments, therapeutic interventions, and surgical procedures in aspects related to diseases and joint malformations.

\footnotetext{
${ }^{1}$ Laboratório de Anatomia Funcional Aplicada à Clínica e à Cirurgia (LAFACC), Universidade de São Paulo - USP, Avenida Prof. Lineu Prestes, 2415, Cidade Universitária, CEP 05508-900, São Paulo, SP, Brazil.+55(11)992792701 maricdonato@ gmail.com

${ }^{2}$ Faculdade de Medicina Veterinária da Universidade Santo Amaro (UNISA), São Paulo - SP, CEP 04743-030, Brazil.

${ }^{3}$ Hospital Albert Einstein, Avenida Albert Einstein 627, Prédio A-1, sala 301, Jardim Leonor, São Paulo - SP, CEP 05652-900, Brazil.
} 


\section{MATERIAL AND METHOD}

The research was approved by the Human Research Ethics Committee of the Institute of Biomedical Sciences of the University of São Paulo (case N.1320/HREC/ICB-III - USP) and the Animal Ethics Committee (AEC) of the Faculty of Veterinary Medicine and Zootechnics of the University of São Paulo (case N. 2241030816/ FMVZ-USP).

Twenty human fetuses with ages between 16 and 31 weeks of IUL were used in the present study. These specimen were obtained from the didactic collection biorepository of the Department of Anatomy of the ICB III - USP and were previously fixed in $10 \%$ formalin solution. Fetuses were divided into 4 groups $(\mathrm{n}=5)$ : Group 1 (G1): 16-19 weeks IUL; Group 2 (G2): 20-23 weeks IUL; Group 3 (G3): 24-27 weeks IUL and Group 4 (G4): 28-31 weeks IUL.

The hip joint region was dissected bilaterally and submitted to a frontal section in its middle portion. The anterior and posterior halves of the right antimer were decalcified by immersion in $7 \%$ ethylenediaminetetraacetic acid (EDTA) and prepared for light microscopy. Semiserial frontal cuts sections of $5 \mu \mathrm{m}$ (micrometers) thick were stained by the methods of Masson Trichrome (MT) to determine the morphometric parameters (chondrocyte area, chondrocyte density and extracellular matrix - ECM) according to Mandarim-de-Lacerda \& del Sol (2017). The chondrocyte volume was estimated throught the stereological nucleator method (Gundersen, 1988). The qualitative analysis of the cartilaginous matrix was performed in sections stained with Safranin-O (Luna, 1968), and the distinction of collagen fibers was carried out with picrosirius examined under polarized light (Junqueira et al., 1979). The images were obtained using an image analyzer system (Carl Zeiss MicroImaging, Axioscope 40 model) and Axiocam camera, connected to a quantification software Axiovision Rel. 4.8. (Zeiss).

The anterior and posterior halves of the left HJ antimer were processed by routine scanning electron microscopy methods (Gründer, 2006) and analyzed with a scanning electron microscope (SEM) (Model: LEO 435 VP, Department of Anatomy of Domestic and Wild Animals, Faculty of Veterinary Medicine and Animal Science).
The data related to the chondrocyte area, chondrocyte density and ECM and chondrocyte volume, expressed as mean \pm standard deviation (SD) were assessed by oneway Analysis of Variance (ANOVA) followed by comparisons between the different groups using the Tukey method (Zar Jerrold., 1984).

\section{RESULTS}

Significant differences were found between the groups $(\mathrm{p}<0.05)$ for the area and volume of chondrocytes as well as for the percentage density of chondrocytes and ECM, as shown in Table I.

For chondrocyte density, a gradual decrease was observed from G1 to G4. This one was significantly different from the other groups. Unlike the values found for chondrocyte density, the EMC density increased along the aging process.

The analysis of the types of collagen fibers by the Picro-sirius method under polarized light allowed to differentiate each group (G1, G2, G3 G4), according to the organization, orientation and predominant types of collagen fibers. In G1 predominated the blue and thin type II fibers; In $\mathrm{G} 2$ and G3, the fibers are shown in yellow and green with intermediate thickness and in G4 fibers were predominantly greenish and organized in a pantograph mesh (Fig. 1).

The three-dimensional arrangements of the collagen fibers are shown in Figure 2.

Thus, in the younger group (G1), there was certain stratification towards the surface, where the deeper fibers were organized longitudinally, and the more superficial ones were organized obliquely. This was also evidenced in G2 and G3 and assumes a final characteristic in G4, where the arrangement revealed that the superficial fibers were initially arranged obliquely, assume a transverse path in relation to the long axis of the femoral head.

The qualitative evaluation of ECM density with Safranin-O showed advances in the intensity pattern, ranging from less intense in G1, to more intense in G4. For G2 and

Table I. Mean \pm SD for chondrocyte area, chondrocyte density and ECM density for groups G1, G2, G3 and G4.

\begin{tabular}{ccccc}
\hline Group & Chondrocyte area $\left(\mu \mathrm{m}^{2}\right)$ & Chondrocyte density $(\%)$ & ECM density $(\%)$ & ${\text { Chondrocyte volume }\left(\mu \mathrm{m}^{3}\right)}^{\text {(\%) }}$ \\
\hline G1 & $107.6 \pm 14.4$ & $0.694 \pm 0.139$ & $0.306 \pm 0.139$ & $2536.5 \pm 759.0$ \\
G2 & $126.6 \pm 21.7$ & $0.564 \pm 0.048$ & $0.436 \pm 0.048$ & $3307.0 \pm 648.2$ \\
G3 & $168.9 \pm 15.9$ & $0.462 \pm 0.044$ & $0.538 \pm 0.044$ & $4305.5 \pm 1074.9$ \\
G4 & $168.6 \pm 48.1$ & $0.348 \pm 0.047$ & $0.652 \pm 0.047$ & $5716.8 \pm 2263.8$ \\
\hline
\end{tabular}



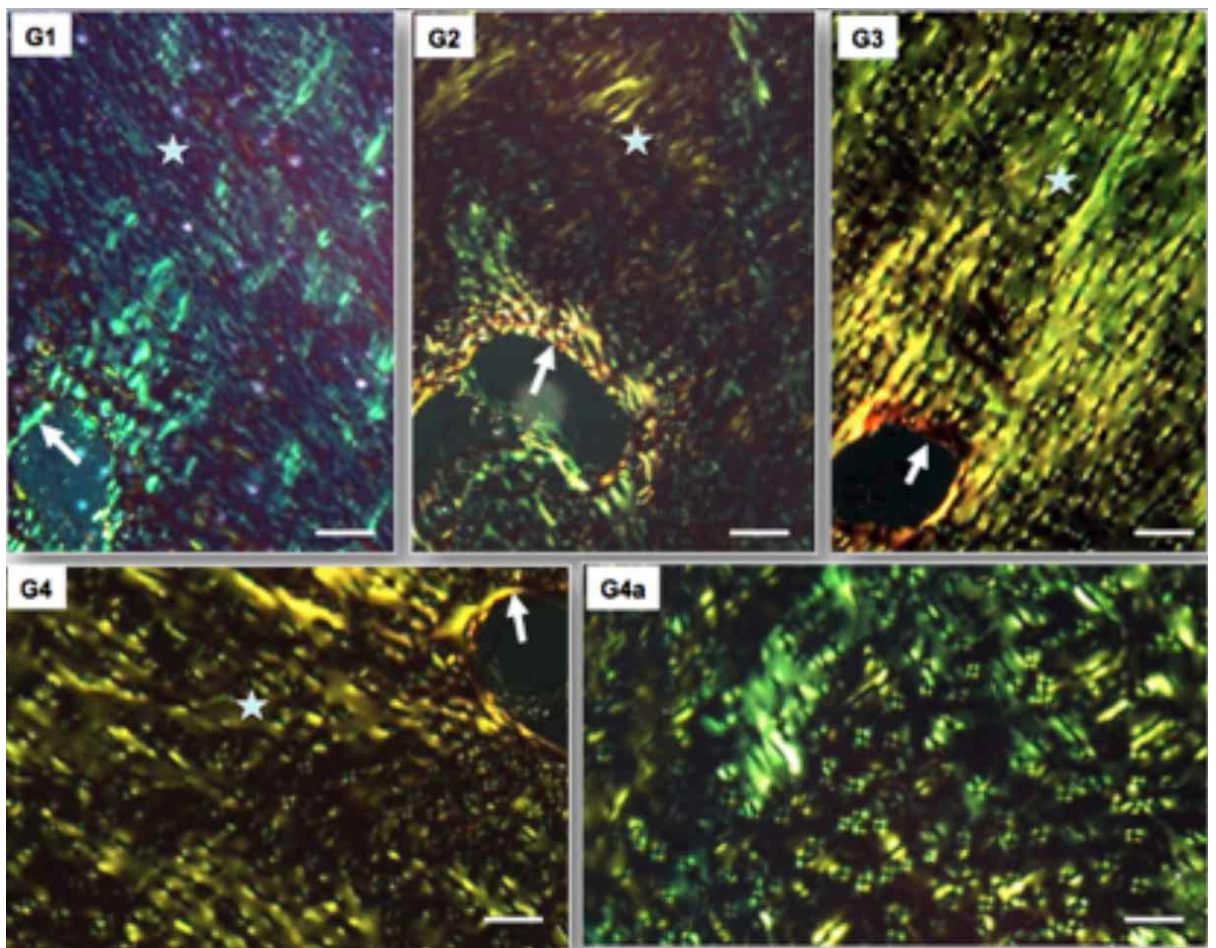

The three-dimensional analysis of articular surface by SEM in G1 revealed an uneven surface, with shallow and deep grooves, giving it a wrinkled aspect. In G3 and G4, the 3D surface was virtually flat, with elongated and discreet projections along its extension. G2 specimens exhibited an intermediate appearance, with thick and elongated projections, separated by relatively deep depressions. In G1 and G2, the chondrocytes were more densely distributed in the middle part of the cartilage. However, in G3 and G4, where the EMC density was higher, there were more dispersed distribution of chondrocytes (Fig. 4).

Fig. 1. Distribution of polarization colors of collagen fibers in G1, G2, G3 and G4 (Picrosirius staining under polarized light. Calibration bar: $20 \mu \mathrm{m}$ ).

G3, no significant differences were found between the groups, which showed an intensity pattern greater than G1 and lower than G4 (Fig. 3).

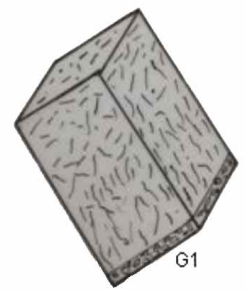

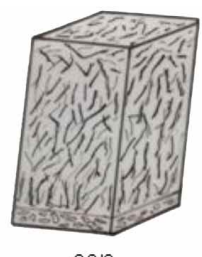

$\mathrm{G} 2 / 3$

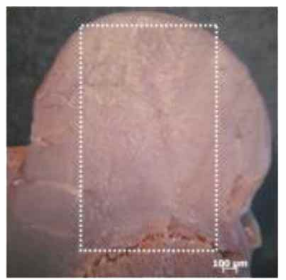

Fig. 2. Three-dimensional organization of the collagen fibers in articular cartilage of the femur head in G1, G2, G3 and G4.
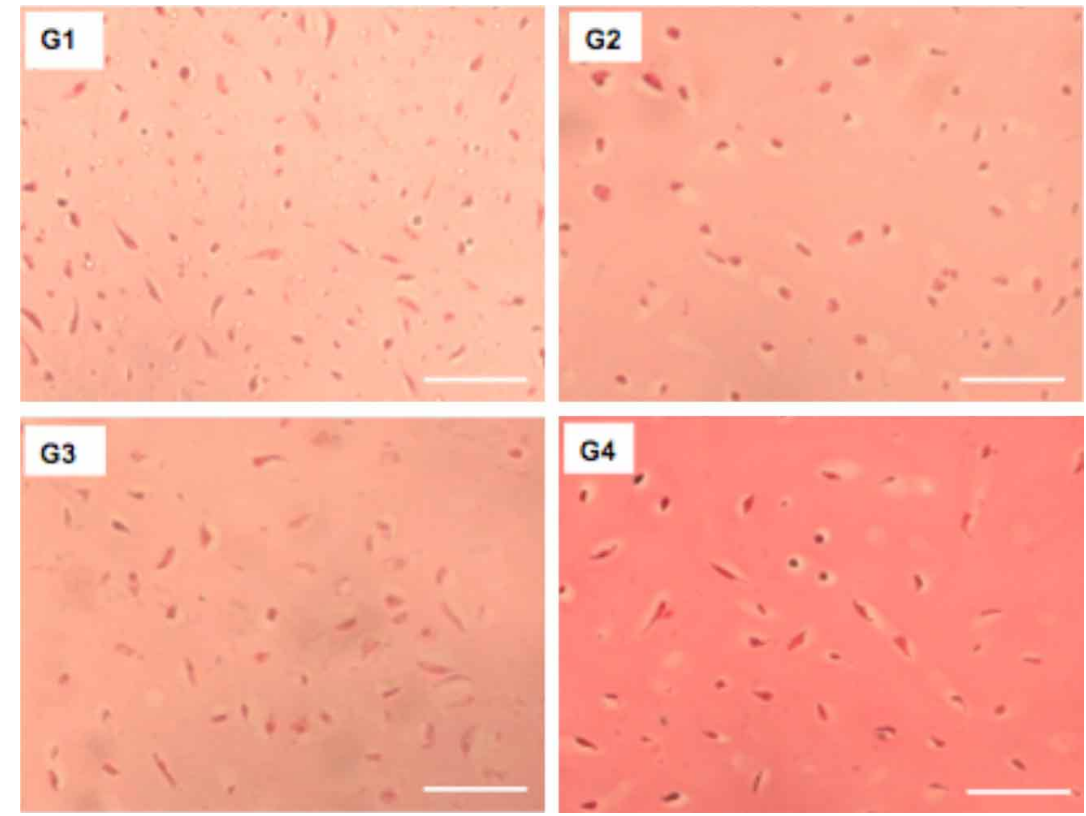

Fig. 3. The extracellular matrix (ECM) in different groups. Note the lighter coloring in G1; intermediate in $\mathrm{G} 2$ and $\mathrm{G} 3$, and more intense in G4. (Safranin-O. Calibration bar: $50 \mu \mathrm{m}$ ). 


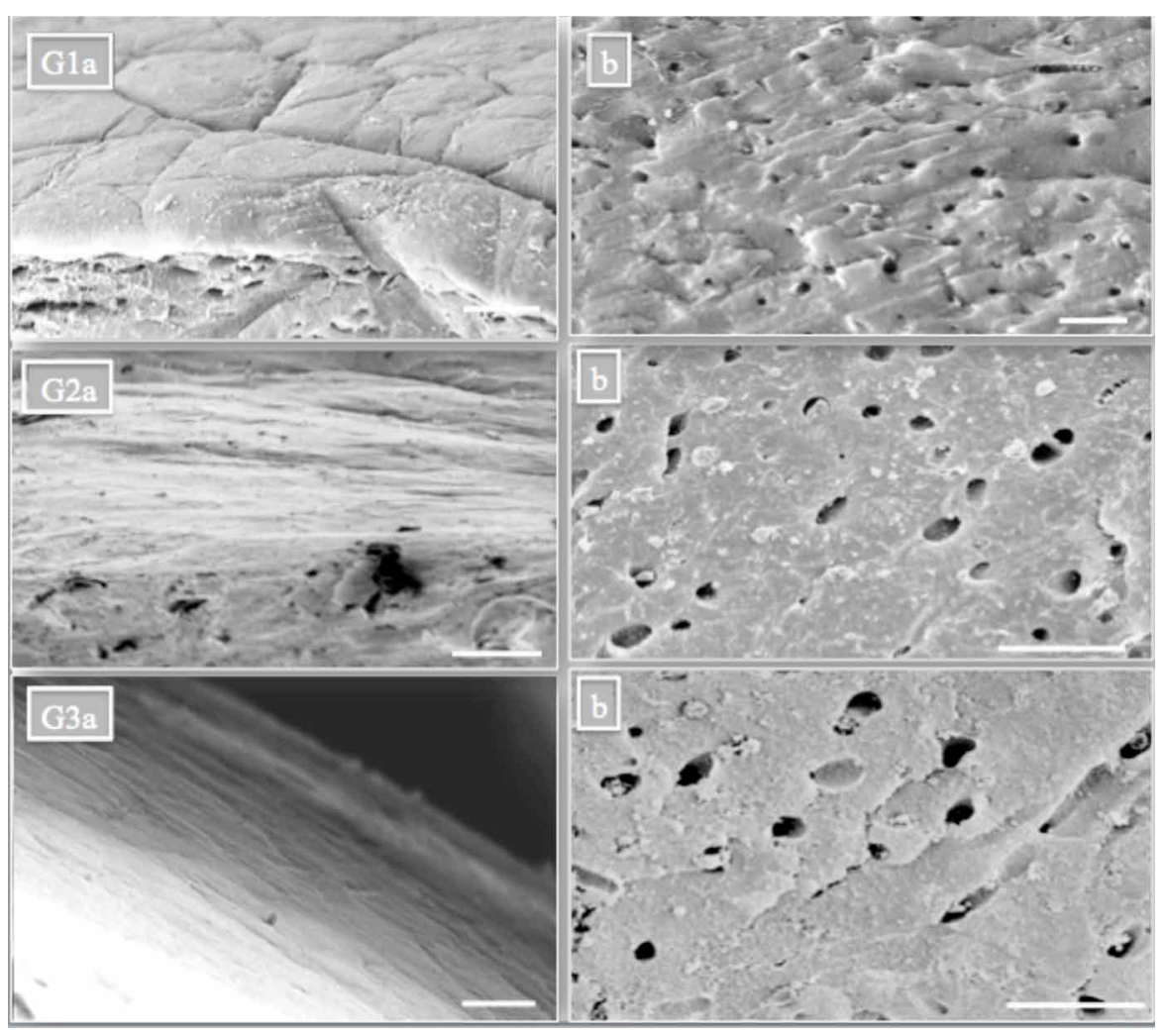

Fig. 4. Scanning electromyrographs of the articular surface and the middle part of the cartilage in G1a, G2a and G3a (G4a). Detail of the loci of chondrocytes according to their quantity in G1b, G2b and G3b (G4b) (Calibration bar: $30 \mu \mathrm{m})$.

\section{DISCUSSION}

It has been described that the influence of normal and pathological stress affect the cartilage, and therefore, the differentiation of chondrocytes. To understand how the subtle application of normal mechanical stress leads to the appropriate development of limbs and cartilage is important to plan therapies that facilitate the cartilage tissue engineering approaches (Zuscik et al., 2008).

In their studies on cartilage maturation and chondrocyte differentiation, Chen et al. (1995) reported that the development of these cells can be divided into the distinct zones: proliferation, maturation and hypertrophy, ordered from superficial to deep cartilage zones. The chondrocytes in the zone of proliferation are densely arranged, whereas in the maturation zone, they are sparser. Jadin et al. reported that the cartilage tissue maturation during fetal development, particularly in the epiphysis, was related to the changes in the cartilage tissue organization, when the chrondrocytes were sparser. In the present study, chondrocytes were more densely arranged in the two initial stages (G1 and G2), unlike in the last two groups (G3 and G4), which showed a more dispersed distribution of chondrocytes and with increased EMC density.

The biomechanical behavior of the hyaline cartilage is associated with a network of type II collagen fibers and the hydrated ECM components, that reconfigure the collagen and associated proteins network (Han et al., 2011). The resistance of the articular cartilage to stretching (up to $5 \%$ of the initial length) and to shear stress is largely due to the organization of the collagen fibers. The compressive force exerted on the cartilage can modify its structure and composition, resulting in a change in the biomechanical behavior, making it return to the initial position due to its viscoelastic properties (Poole, 1997). Picrosirius staining examined under polarized light allowed to differentiate each group (G1, G2, G3 and G4), according to the organization, orientation and predominant types of collagen fibers. According to Treilleux et al. (1992), Todhunter (1996) and Eurell \& Sickle (1998), type II collagen is the predominant fibrous component making up $90-95 \%$ of the primary collagen in ECM, which was proven here since the G1 fetuses with a predominance of type II collagen fibers, oriented in thick and irregular mesh-like network. These authors have reported that type I and III collagen fibers were also found in the 22nd week of fetal development, which corroborates the findings of the present study for the same gestation period (G2). In contrast, G4 showed a high density of type III collagen fibers.

The highly organized collagen fiber structure in the cartilage matrix is formed by arcades, resembling gothic columns, in a vertical direction through the cartilage (Benninghoff, 1925). Muehleman et al. (2004) and Cluzel et al. confirmed this finding using X-ray radiography. For Hyttinen et al. (2009), large changes in joint loading during growth and maturation profoundly affect the architecture of the collagen network.

The spatial architecture of the collagen fiber network forms an interwoven mesh that compresses and returns to the initial position, mainly in the surface area of articular 
cartilage (Hyttinen et al.). However, the structural organization of the collagen fibers is not affected by compressive forces and weight exerted on the cartilage, since in the fetuses of the present study, the architectural arrangement of collagen fibers was organized earlier. In fact, according to Cluzel (2012), the early stratification of the collagen network is present before birth and therefore, before being submitted to joint loading. These findings suggest that in G4 the articular cartilage was properly organized, even without the presence of compressive forces on its surface.

With the use of a stereological method, which allows to estimate the number of chondrocytes per unit volume of tissue and to associate the size growth of chondrocytes from different age groups (Hunziker et al., 2002), we statistically observed that the average volume was proportional to the aging process. Therefore, the fetuses in G4 were those that have reached the "peak" of development, characterized by a higher increase in chondrocyte volume (observed from G3 to G4), the initial step of differentiation of these cells, according to Zuscik et al.

The SEM images is shown to be a wavy cartilage surface in $\mathrm{G} 1$ as a result of the heterogeneous organization of the collagen network in the surface layer, making it flat according to the aging progress. This description corroborates with the descriptions of Todhunter, who reported a more uniform structural organization of the cartilage in adults.

The results obtained in the present study suggest that the collagen organization in joint cartilage is established in the very early fetal stage and evolves during the development to form the known adult structure. There was a gradual increase in chondrocyte area and volume and in ECM density with advanced aging concurrently to a decrease in the chondrocyte density percentage. The pantographic organization of the collagen fiber meshes from the depth to the cartilage surface of the femoral head suggests that the collagen network arcades architecture started at 16 weeks of IUL (G1).

A development pattern has been established between 16 to 31 weeks of IUL of the proximal epiphysis of the femur where the biomechanical behavior of articular cartilage is associated with the orientation and arrangement of collagen fibers and the components present in ECM. This area prepare itself to receive the load, contributing to the properties required in cartilage at each stage of development, such as resistance to tension, resistance to compression and the ability to distribute loads.

\section{ACKNOWLEDGEMENTS}

The authors are grateful to Rosana D. Prisco for the statiscal analysis; Marta M. Righetti for the light microscopy; Rose E. Grassi for the scanning electromyrographs; Sebastião A. Boleta and Sônia R. Y. Almeida for the scanning electron microscopy images.

SIMÕeS, M. C. D.; AGOPIAN, R. G.; CABRITA, H. A. B. A. \& LIBERTI, E. A. Evaluación morfofuncional y ultraestructural del desarrollo de la articulación de la cadera en fetos humanos. Int. J. Morphol., 37 (4):1450-1455, 2019,

RESUMEN: El desarrollo secuencial normal de la articulación de la cadera (AC) se consideró para la evaluación de los aspectos morfológicos y ultraestructurales del cartílago articular de la epífisis proximal y de la cabeza femoral en fetos humanos entre 16 y 31 semanas de vida intrauterina (SVIU). Veinte fetos humanos fueron fijados en solución de formalina al 10 $\%$. Los fetos se dividieron en 4 grupos $(\mathrm{n}=5)$ : Grupo 1 (G1), 1619 semanas de IUL; Grupo 2 (G2), 20-23 semanas SVIU; Grupo 3 (G3), 24-27 semanas SVIU y Grupo 4 (G4), 28-31 semanas SVIU. Las muestras derechas de la AC se sometieron a microscopía óptica para determinar el área, el volumen y la densidad de los condrocitos y la densidad de la matriz extracelular (MEC). El componente de colágeno en la MEC se evaluó cualitativamente utilizando técnicas de safranina-O y picrosirius bajo luz polarizada. Las muestras de la AC izquierda se analizaron utilizando microscopía electrónica de barrido (MEB). El avance de la edad reveló un aumento gradual en el área y el volumen de los condrocitos y en la densidad de la MEB, y una disminución en la densidad de los condrocitos. La aparente prevalencia de las fibras de colágeno tipo II en G1 y tipo III en G4, así como el equilibrio entre las fibras de colágeno tipo I y III en G2 y G3 sugieren un proceso de evolución y reparación cartilaginosa. La organización pantográfica de las mallas de fibra de colágeno desde la profundidad a la superficie del cartílago de la cabeza femoral sugiere que la arquitectura de la red de colágeno comienza en la etapa fetal, independientemente de las fuerzas compresivas aplicadas. Los datos morfológicos pueden contribuir no solo a una mejor comprensión de la organización de la maduración y el cartílago en esta área, sino también servir de base teórica para los aspectos relacionados con enfermedades y malformaciones articulares.

PALABRAS CLAVE: Anatomía; Feto humano; Articulación de la cadera; Condrocitos; Colágeno.

\section{REFERENCES}

Benninghoff, A. Spaltlinen am Knochem, eine Mrthode zur Ermittlung der Architektur platter Knochen. Verhandlungen der Anatomischen Gesellschaft, 34:189, 1925. 
Chen, Q.; Johnson, D. M.; Haudenschild, D. R. \& Goetinck, P. F. Progression and recapitulation of the chondrocyte differentiation program: cartilage matrix protein is a marker for cartilage maturation. Dev. Biol., 172(1):293-306, 1995.

Cluzel, C. Développement du Cartilage Articulaire Équin du Fætus à L'Adulte: Imagerie par Résonance Magnétique et Microscopie en Lumière Polarisée. Master in Veterinary Sciences. Montreal, Université de Montréal, 2012.

Cluzel, C.; Blond, L.; Fontaine, P.; Olive, J. \& Laverty, S. Foetal and postnatal equine articular cartilage development: magnetic resonance imaging and polarised light microscopy. Eur. Cell. Mater, 26:33-47, 2013.

Fukazawa, I.; Hatta, T.; Uchio, Y. \& Otani, H. Development of the meniscus of the knee joint in human fetuses. Congenit. Anom. (Kyoto), 49(1):2732, 2009.

Gründer, W. MRI assessment of cartilage ultrastructure. N. M. R. Biomed., 19(7):855-76, 2006.

Gundersen, H. J. G. The nucleator. J. Microsc., 151(1):3-21, 1988.

Han, L.; Frank, E. H.; Greene, J. J.; Lee, H. Y.; Hung, H. H.; Grodzinsky, A. J. \& Ortiz, C. Time-dependent nanomechanics of cartilage. Biophys. J., 100(7):1846-54, 2011.

Hunziker, E. B.; Quinn, T. M. \& Häuselmann, H. J. Quantitative structural organization of normal adult human articular cartilage. Osteoarthritis Cartilage, 10(7):564-72, 2002.

Hyttinen, M. M; Holopainen, J.; van Weeren, P. R.; Firth, E. C.; Helminen, H. J. \& Brama, P. A. J. Changes in collagen fibril network organization and proteoglycan distribution in equine articular cartilage during maturation and growth. J. Anat., 215(5):584-91, 2009.

Jadin, K. D.; Wong, B. L.; Bae, W. C.; Li, K. W., Williamson, A. K.; Schumacher, B. L.; Price, J. H. \& Sah, R. L. Depth-varying density and organization of chondrocytes in immature and mature bovine articular cartilage assessed by $3 \mathrm{~d}$ imaging and analysis. J. Histochem. Cytochem., 53(9):1109-19, 2005.

Junqueira, L. C.; Bignolas, G. \& Brentani, R. R. Picrosirius staining plus polarization microscopy, a specific method for collagen detection in tissue sections. J. Histochem.. 11(4):447-55, 1979.

Li, L. Y.; Zhang, L. J.; Jia, J. Y.; Zhao, Q.; Wang, E. B. \& Li, Q. W. Does dynamic immobilization reduce chondrocyte apoptosis and disturbance to the femoral head perfusion? Int. J. Clin. Exp. Pathol., 6(2):212-23, 2013.

Luna, L. G. Histologic Staining Methods of the Armed Forces Institute of Pathology. $3^{\text {rd }}$ ed. New York, Mc Graw-Hill, 1968.

Mandarim-de-Lacerda, C. A. \& del Sol, M. Tips for studies with quantitative morphology (morphometry and stereology). Int. J. Morphol., 35(4):1482-1494, 2017.

McCarthy, D. J. Anatomical basis for congenital deformities of the lower extremities. Part II. The knee and leg. J. Am. Podiatr. Med. Assoc., 83(3):130-8, 1993.

Muehleman, C.; Majumdar, S.; Issever, A. S.; Arfelli, F.; Menk, R. H.; Rigon, L.; Heitner, G.; Reime, B.; Metge, J.; Wagner, A.; et al. X-ray detection of structural orientation in human articular cartilage. Osteoarthritis Cartilage, 12(2):97-105, 2004.

Poole, C. A. Articular cartilage chondrons: form, function and failure. $J$. Anat., 191(Pt. 1):1-13, 1997.

Tecklenburg, K.; Dejour, D.; Hoser, C. \& Fink, C. Bony and cartilaginous anatomy of the patellofemoral joint. Knee Surg. Sports Traumatol. Arthrosc., 14(3):235-40, 2006.

Todhunter, R. J. Anatomy and Physiology of Synovial Joints. In: C.W. McIlwraith, Trotter, G. W. (Eds.). Joint Disease in the Horse. Philadelphia, W. B. Saunders Company, 1996. pp.1-28.

Treilleux, I.; Mallein-Gerin, F.; le Guellec, D. \& Herbage, D. Localization of the expression of type I, II, III collagen, and aggrecan core protein genes in developing human articular cartilage. Matrix, 12(3):221-32, 1992.

Walker, J. M. \& Goldsmith, C. H. Morphometric study of the fetal development of the human hip joint: significance for congenital hip disease. Yale J. Biol. Med., 54(6):411-37, 1981.
Zar Jerrold, Z. H. Biostatistical Analysis. $2^{\text {nd }}$ ed. Englewood Cliffs, Prentice-Hall Inc., 1984.

Zuscik, M. J.; Hilton, M. J.; Zhang, X.; Chen, D. \& O'Keefe, R. J. Regulation of chondrogenesis and chondrocyte differentiation by stress. J. Clin. Invest., 118(2):429-38, 2008.

\author{
Corresponding author: \\ Mariane Cristina Donato Simões \\ Laboratório de Anatomia Funcional Aplicada \\ à Clínica e à Cirurgia (LAFACC) \\ Universidade de São Paulo - USP \\ Avenida Prof. Lineu Prestes, 2415 \\ Cidade Universitária \\ CEP 05508-900 \\ São Paulo, SP \\ BRAZIL
}

Email: maricdonato@gmail.com

Received: 01-05-2019

Accepted: 01-07-2019 